\title{
sciendo
}

Iryna Shandra (Kharkiv State Academy of Culture, Kharkiv)

ORCID: 0000-0002-9092-413X

irina_shandra@ukr.net

Olena Kravchenko (Ukrainian State University of Railway Transport, Kharkiv)

ORCID: 0000-0001-6524-1997

kravchenko@kart.edu.ua

\section{CONGRESSES OF MINING INDUSTRIALISTS OF THE SOUTH OF RUSSIA AND THE KINGDOM OF POLAND AS A FORM OF REPRESENTING ENTREPRENEUR'S INTERESTS (END OF THE 19th - BEGINNING OF THE 20th CENTURY)}

\begin{abstract}
The article analyzes the process of creating and functioning of two representative organizations of entrepreneurs - the Congress of Mining Industrialists of the South of Russia (1874, Kharkiv) and the Congress of Mining Industrialists of the Kingdom of Poland (1882, Warsaw). Both institutions were a form of activity of the regional economic elites and represented their socio-economic interests. After a comparative analysis of associations of mining industrialists in Ukrainian and Polish territories, the article highlights common features, their structure, forms of activity and representative powers. Based on the research, it was found that, despite strict government control, they played an important role in defending local interests and developing the industry they represent, and the fruitful cooperation of the Miners' Congresses of the South of Russia and the Kingdom of Poland allowed for the implementation of the agreed and, above all, effective pressure on the state authorities of the Russian Empire.
\end{abstract}

Keywords: representative organization of entrepreneurs, Congresses of Mining Industrialists of the South of Russia, Congresses of Mining Industrialists of the Kingdom of Poland, economic elite, Russian Empire

doi: $10.2478 /$ sho-2020-0008 


\section{INTRODUCTION}

The cooperation of power and capital is the most important problem and current task in the development of countries and nations, because establishing effective mechanisms of interaction between them ensures stability and economic prosperity of the society. Such a form of interaction between the industry and state officials of the Russian Empire at the turn of the 19th and 20th centuries was the relationship between the authorities and representative organizations of entrepreneurs in the mining and metallurgical industries.

The formation of these associations is one of the significant problems in the development of the capitalist economy and creation of the foundations for self-organization of the society of the Russian Empire. Researching it allows us to correctly imagine the relations of the dominant social forces in the country, understand the social nature of state power and the mechanisms of government. As the eminent scientist D. Mendeleev wrote about the Congress of Industrialists, "this topic is multifaceted, controversial and should be discussed in a special and detailed manner" [Менделев Д.И. 1888: 14].

The Congresses of Mining Industrialists of the South of Russia and the Congresses of Mining Industrialists of the Kingdom of Poland were a kind of representation of the interests of big capital, a symbiosis of business aspirations on the one hand, and forms of representation permitted by the Russian Empire on the other. Both mining regions had common problems and tasks, which was reflected in the identity of the structure of these organizations as well as the main directions and methods of their operation.

\section{RESEARCH CONTEXTS AND OBJECTIVES}

The study of the activities of the Congresses of Mining Industrialists of the South of Russia and the Kingdom of Poland became possible thanks to the use of the source materials of these associations ("Трудов..." (“Works..."), “Протоколов заседаний..." ("Minutes of meetings...") etc.), their statutory documents and other regulations ("Свод законов Российской империи..." ("Code of the Laws of the Russian Empire..."), "Собрание узаконений и распоряжений..." , many magazines from the analyzed period (“Торгово-промышленный Юг” (“Commercial and 
industrial South"), “Горный журнал" (“Mining magazine”), “Южно-русский горный листок” “Экономист России” ("Economist of Russia”), “Промышленность и торговля" ("Industry and trade”), archival materials. In Ukrainian historiography, the problem of representative organizations of entrepreneurs was examined in the works of L. Kornijczuk, W. Krutikow, and I. Shandra. This article uses information from the scientific research of such Polish researchers as J. Kofman, R. Kowalczyk, I. Pietrzak-Pawłowska, J. Piłatowicz, P. Frączak.

The aim of the article is a comparative analysis of two representative organizations of entrepreneurs (Ukrainian lands - the Congress of Mining Industrialists of the South of Russia, Polish - the Congress of Mining Industrialists of the Kingdom of Poland), identifying common and characteristic features, discussing their interaction and mutual influence.

\section{CAUSES AND CONDITIONS \\ OF CREATING REPRESENTATIVE ORGANIZATIONS}

The second half of the nineteenth and early twentieth centuries was a time of rapid development of new socio-economic relations. Rapid production growth after the abolition of serfdom, the emergence of new areas of management, the complexity of production and organizational forms in the economy - all these contribute to the creation of an extensive system of representative associations of entrepreneurs.

In fact, there was no such area where the represented institutions (organizations of sugar producers, millers, carriers, the mining industry, oil, gold, and even fish and seal breeding) would not have function) [Гушка А.О. 1912: 47; Съезд рыбо... 1908: 265]. Official and private, industry and general, local, regional or all-imperial - all these organizations not only fulfilled their immediate goal - to influence the state authorities and public opinion, but also became one of the manifestations of the self-organization of social groups, which under the conditions of a monarchicalbureaucratic system were a particular phenomenon, evidence of profound changes not only in management methods, but also in the awareness of capital representatives.

Establishing representative organizations was in the common interest of the state and capital. According to the representatives of the authorities, the activity of representative institutions of entrepreneurs was very important in managing the country's economy. They were useful in the prep- 
aration of laws on socio-economic issues; and the mere interaction with industrialists gave the monarchy a sense of stability and support among the rich. By building cooperation with such organizations, the government, in addition to practical benefits, had the ability to legally control and direct the permitted forms of industrialist representation in the desired direction. Russian politicians strongly supported the idea of representation for industrial interests. Among other things, S. Witte noted: "Organize yourselves so that you can convene general and district congresses periodically to have permanent offices or other institutions that will unite you. Have your own press to explain all your interests in their proper light, to defend them from the public and prepare them for administration to the government..." [Пажитнов К. 1907: 13].

For their part, along with the development of industrial production and the accumulation of economic potential, entrepreneurs themselves initiated the creation of representative organizations. The new social force not only wanted to participate in making decisions, but also felt responsible for their implementation. The gradual transition of entrepreneurs to the economic elite of the post-reform society made it an immediate issue to create business corporations that would represent their interests in public authorities and act as an instrument of influence on the economic policy of the government.

Entrepreneurs from the energy sector (or industry) were the first to set up representative organizations representing the private sector in this industry [Шандра I. 2011: 45], because this is where the dependence on the economic policy of the state occurred the most. Undoubtedly, the tax, railroad, customs and other types of government activities could be in conflict with the interests of entrepreneurs. The improvement of production techniques, the division of state orders, the creation of a positive image of heavy industry in society required due attention from entrepreneurs. The most important of these associations were: Congress of Mining Industrialists of the South of Russia (1874), Congress of Mining Industrialists of the SubMoscow Region (1880), Congress of Mining Industrialists of the Urals (1880), Congress of Mining Industrialists of the Kingdom of Poland (1882) the so-called "old guard of the industrial class" [Шандра I.O. 2016: 132].

The main purpose of the representative organizations was to agree on individual business interests and to present common demands to public authorities. The forms of work of the associations initially consisted in collecting statistical data and submitting petitions to governmental institutions. Through systematic pressure on the authorities and society, these 
associations influenced state institutions that shaped the economic and social policy of the country. That is why these organizations are best characterized by the name "representative", which reflects their main characteristic [Шандра I.O. 2016: 80].

The industry conventions of entrepreneurs were created on the basis of the historically complex process of shaping the regional economic elites and economic zones of the Russian Empire. According to the words of the contemporary Russian researcher T. Krasilnikova, "The Russian Empire in economic terms represented a combination of several regional economies, each of which had a specific resource base, economic and cultural traditions" [Красильникова Т.К. 2011: 49]. The process of creating representative organizations of miners in the Southern Economic Region and the Kingdom of Poland was a demonstration, which reflected the degree of organization of the economic elite of these lands, their participation in the general social processes, as well as the character of the development of the industry united by them.

In terms of the pace of economic development, the Southern economic region, which included the south-eastern Ukrainian governorates, was ranked first in Russia at the turn of the 20th century. Mining has emerged as a colossus here, causing significant overall economic growth in the region. This fact was often emphasized by scientists. The outstanding Russian chemist D. Mendeleev in his work "The future of strength that lies on the banks of the Donets" wrote with delight that "of all Russian hard coal deposits, the nearest railways, the most important for the future, the oldest, and perhaps the richest - is undoubtedly Donetsk" [Менделеев Д.И. 1960: 411]; and the famous Ukrainian economist M. Tugan-Baranowski emphasized that the production in this area, "organized entirely in the capitalist system, is the newest and greatest flower of Russian industrial capitalism" [Туган-Барановский М. 1938: 259].

The geographical location of the Kingdom of Poland, its national and cultural characteristics, as well as moral, ethical and legal norms were also a kind of determinants, which had a decisive influence on the character and development of the local mining industry. The Polish economic elite emphasized that "the industry of the Kingdom of Poland needs the proper organization of its representative office in order to, on the one hand, eliminate and reconcile internal controversies, and on the other - to defend local interests in government institutions, and in this way, to improve the economic conditions of the region" [Организация промышленников... 1911: 49-50]. 


\section{ORGANIZATIONAL STRUCTURE OF THE CONGRESSES OF MINING INDUSTRIES OF THE SOUTH OF RUSSIA AND THE KINGDOM OF POLAND}

In the conditions of the monarchical system, in which there were no representative legislative authorities, industrial circles initiated the creation of representative business organizations. The first steps to establish a regional industry representative corporation were taken by the Congress of Miners of the South of Russia. Throughout its formation period, it encountered many obstacles. First, it was necessary to obtain the approval of the Committee of Ministers to organize the Miners' Convention in South Russia. According to this document, from June 14, 1874, the head of the mining district of Lugansk received the right to convene to discuss the topics "on the needs of the mining industry" [Высочаиче утвержденное... 1874: 921]. The first Congress of Mining Industrialists of the South of Russia was convened on November 10, 1874 in Taganrog by the Minister of State Property, Mr. Waluyev, after consultation with the Ministers of the Military and Railways.

At the turn of the 19th and 20th centuries, all representative organizations of large capital underwent a similar way of obtaining agreement and "the highest authorization" to operate. Their formation took place in the absence of coalition law, when the government viewed the NGOs as unacceptable and the actions of their founders resembled "torture." Governors had the right to close any private companies "to protect state security" [Оржеховский И.В. 1974: 65]. The conventions of mining industrialists of the Kingdom of Poland were also organized on the basis of the decision of the Committee of Ministers of May 14, 1882 on the order of the Minister of State Property "in order to discuss the needs of the local mining industry" [Труды Первого... 1883: 5]. It was from this date that the history of the Miners' Congresses of the Kingdom of Poland began. Regulations for both decisions of the Committee of Ministers (concerning the Congresses of Mining Industrialists of the South of Russia and the Kingdom of Poland) were included in the "Mining Statute". According to Art. 35 of this code, the Minister of State Property had the right to convene miners of various regions "when and where necessary" to discuss the problems of the "local mining industry" [Съод законов Российской империи... 1893: 9]. This article clearly emphasized the Minister's priority to convene congresses. The established legal status of business organizations characterized them as aux- 
iliary structures, the creation of which was related to the needs of bureaucratic management.

The government strictly regulated the work of mining conventions and made sure that the atmosphere of business meetings remained within the limits of business contacts. Therefore, the chairman of the first Congress of Mining Industrialists of the South of Russia, mining engineer Eugeniusz B. Ivanitsky was warned about the need to comply with the procedure and content of the questions permitted by the government [Крутіков В.В. 1992: 49]. A secret letter from the Ministry of State Property to the chairman expressed the conviction that he would not allow outside talks, and would favor important and reserved debates [Корнійчук Л.Я. 1971: 62]. Similar recommendations regarding the necessity of strict adherence to the established program of meetings were heard at the Congress of Mining Industrialists of the Kingdom of Poland [Труды II Съезда горнопромыиленников... 1886: II; Третий съезд... 1893: 524]. Тhe First Congress of Miners of the South of Russia in 1874, positively received by the inhabitants of Taganrog, ended with a joint lunch of all its participants, organized by the city authorities [Ауэрбах А.А. 1909: 464]. The first Congress of Miners in the Kingdom of Poland in 1883 was held with much more pathos in the magnificent hall of the City Hall of Warsaw with the participation of the city president, Lieutenant General S. Starynkiewicz [Труды Первого ... 1883].

Both the first Congress of Mining Industrialists of the South of Russia (1874) and the Congress of Mining Industrialists of the Kingdom of Poland (1883), formulated a broad program of desired changes and "government awards" necessary for the industrial development of both regions. The petitions addressed to the government covered a wide range of financial, production, transport and marketing issues, which, according to the entrepreneurs, were to favor the development of mining. Some parts of the petitions presented to the government sounded strange, for example: demands were made to "remove the damage from the vicinity of the pump room" (1st Congress of Miners of the South of Russia [Горнозаводское дело... 1875: 10]) or "to grant the mining workers of the 2nd Mining District the right for storing explosives in a government shop in the village of Suchedniów" (1st Congress of Miners of the Kingdom of Poland [Труды Первого... 1883: VIII]).

The first meetings of miners were convened each time with the consent of the Minister of State Property; and these organizations did not have an approved statutory document. At that time, they could not even be 
called organizations in the full sense of the word: both government officials and entrepreneurs perceived conventions more as an arena for business communication, reconciling interests and reaching compromises. It was only with the passage of time that entrepreneurs obtained approval of the founding documents, thus trying to transform their meetings into a permanent representative organization.

In the years 1878-1885, work continued on the first "Regulations..." of the Miners' Congresses of the South of Russia, which resulted in the approval of the statute of this representative corporation (April 27, 1885) [Шандра I.O. 2011: 51-2; Положение о горнопромыиленных... 1885: 154750]. By adopting this document, the government explicitly recommended that the "Regulations..." of the Congress of Miners of the Kingdom of Poland be "similar to the previous organization of the Congress of Miners in the South of Russia" [Третий съезд... 1893: 516]. In this way, the apparatus of state power expressed a "strong wish" that the new business associations be represented in already tried and controlled forms. The "Regulations..." of the Congress of Miners of the Kingdom of Poland was prepared for discussion at the Third Congress (February 1893) and was approved on November 19, 1893 [Третий съезд... 1893: 521; Положение о съездах... 1904: 183-6].

The founding documents significantly strengthened the status of representative corporations, legally determined the area of their activity. According to the "Regulations...", the southern conventions were to be held annually in Kharkiv, and the Polish ones - every three years in Warsaw (although industrialists from the mining industry offered a meeting place in Dąbrowa). Both corporations shared many features. The program of their work was each time approved by the appropriate ministry, which could introduce changes and supplements at its own discretion. These associations operated on a permanent basis, and their executive bodies (Councils of Congresses) were obliged to provide the government with statistical data on the production volume of the region they represented, participate in the scheduling of mining shipments and provide general information and develop certain projects commissioned by the government [Положение о съездах... 1904: 183; Положение о горнопромыиленных... 1885: 1547-8].

The activities of the Congresses of Mining Industrialists were conducted under the leadership of a government-appointed chairman with the participation of a large number of officials. The chairmen of the Congress of the South of Russia were mining specialists recognized in the civil ser- 
vice - the district engineer of the Mining Districts in Donbas, the actual secret counselor Eugeniusz N. Taskin; head of the Mining Department of South Russia, secret counselor Ivan I. Zielencow; head of the South-Eastern Mining Department, secret counselor Włodzimierz A. Wagner; director and full professor of the Higher School of Mining in Yekaterinoslavia, secret counselor Sergia M. Suczkow, etc. The chairmen at the Congress of Mining Industrialists of the Kingdom of Poland were: the head of the Mining Accounting Commission, secret counselor Alexander A. Jossa; director of the Mining Department, real secret counsel Kontantyn A. Skalkowski; head of the Western Mining Board, actual secret counsel Wincenty W. Choroszewski, etc. Alex P. Keppen, mining engineer, long-term head of the Department of Polish Mining Plants, actual secret counselor, was the chairman of the 3rd Congress of Miners of the Kingdom of Poland (February 1893) and also participated in the Extraordinary Congress Miners in Kharkov (August 1893).

Despite these similarities, the funding of the two organizations varied significantly. The Congress of Miners of the Kingdom of Poland received money on the basis of «voluntary contributions» [Положение о съездах... 1904: 183]; Congress of Miners of the South of Russia had the right to compulsorily "tax" their members: the so-called "voluntary" collection from pood [Свод законов Российской империи ... nо year: 12]. In the third comment to Art. 35 of the «Mining Statute» it was allowed to charge, on the railways of the Mining Area of South Russia, a special fee for each pood of mining cargo (no more than 1/15 kopecks per pood) [Центральний державний..., 2161, record 1, file 8: 8] as reimbursement of costs to finance the activities of the Congress of Miners of the South of Russia [Свод законов Российской империи... 1893: 9; Шандра И.А. 2014: 289]. Increasing the power of the mining and metallurgical industries in south-eastern Ukrainian governorates led to a rapid increase in the organization's budget. If the budget of the First Southern Congress was limited by a modest estimate of $255 \mathrm{ru}$ bles, then at the beginning of the 20th century, the financial capacity of the Congress was 1.5 million rubles per year [Протоколы заседаний съезда.... 1877: 7; Справочная книга... 1916: 71]. The lack of clearly defined sources of financing for miners in the Kingdom of Poland was probably one of the reasons for the more modest annual budgets of this institution: for example, the 3rd Congress (1893) "expressed a willingness to contribute 18,000 rubles per year" [Третий съезд... 1893: 521].

The conventions represented the interests of mostly large industry, usually excluding medium and small entrepreneurs. The statutes of the repre- 
sentative organizations contained paragraphs on the right to vote in a proportional system - depending on the volume of production, entrepreneurs could have one to three votes (Congress of Miners of the South of Russia $\S \S 31,32$ of the "Regulations..." 1899 [Положение о горнопромыиленных... 1904: 182]) or from one to three additional votes (Congress of Miners of the Kingdom of Poland - §§ 27, 28 of the "Regulations..." of 1893) [Положение о съездах... 1904: 186].

The executive body of the representative organizations of miners was the Council of Congresses. Its chairman was a person who had obvious authority among miners in his region. The leaders of the Council of Miners' Congresses in the South of Russia were the leaders of the representative entrepreneurial movement: Apollon F. Mevius (1893-1897), Arkadiusz W. Minenkov (1898-1899), Mikołaj S. Awdakow (1900-1905), Mikołaj F. von Ditmar (1906-97) 1919) [Шандра И.А. 2016: 500].

For many years the chairman of the Council of Miners' Congresses of the Kingdom of Poland ${ }^{1}$ was the spokesman for foreign capital, L. Mauve (until 1899). After him, this position was taken by a representative of the national capital, J. Strasburger (1900-1915), director of the Warsaw Society of Coal Mines and Metallurgical Works [Kofman J. 1968: 104]. J. Strasburger was a co-founder of the Council of Miners' Congresses of the Kingdom of Poland. On her behalf, he repeatedly and successfully made efforts in St. Petersburg to raise tariffs on Polish coal and steel products and to lower rail tariffs, which was to facilitate the export of these products to the western governorates of Russia. He justified his petitions in these matters with economic analyzes, which he presented in the form of papers at the Congress of Mining Industrialists of the Kingdom of Poland and published in "Difficulties of the Congresses" [Pustuła Z., Julian Teofil Strasburger]. The last president of the Council of Miners' Congresses of the Kingdom of Poland after J. Strasburger's death was S. Skarbiński. In this position, he was defending the integrity of the Council despite the division of the Dąbrowa Basin into two German and Austrian occupations. He initiated and started to publish the geological map of the Dąbrowa Basin, the monograph "Mining and steel industry in the Kingdom of Poland" (1918) [Pustuła Z., Stanistaw Skarbinski].

${ }^{1}$ At the 3rd Congress of Mining Industrialists of the Kingdom of Poland (1893), a resolution was adopted to establish a permanent Council [Kazimierz Srokowski....] 


\section{THE MAIN DIRECTIONS OF ACTIVITY AND COOPERATION BETWEEN CONGRESSES OF MINING INDUSTRIALISTS}

The main type of activity of the Miners' Congresses of both regions, the essence of representation as a phenomenon, was the submission of petitions to governments, which had nothing to do with degrading requests, but was a form of vigorous and persistent pressure on state structures. Substantively, these appeals covered the entire spectrum of financial, tax and customs policies, municipal and district government, lending, rail and rail construction tariffs, commercial and industrial law, and labor. On the other hand, the government also frequently made inquiries to representative organizations about their applications. [Шандра I.O. 2011: 107, 11521]. It is not without reason that contemporaries compared representative organizations with the economic parliament, "whose decisions are finally implemented, so [state officials] believe in their proper representation of the needs of the coal industry" [Добролюбов В.А. 1888: 8]. "The lobby of industrialists from the South of Russia was so strong and effective that the Tariff Committee took into account almost exclusively their interests," wrote R. Kowalczyk [Kowalczyk R.W. 2009: 158].

An important component of the interaction of representative corporations with the government were internal mechanisms - constant business communication, participation of congress representatives in councils, and legally established elected representation of the bourgeoisie in government institutions. Representatives of the Miners' Congresses of the Kingdom of Poland and of the Miners' Congresses of the South of Russia were permanent members of the Mining Affairs Department, Mining Council in St. Petersburg and many other organizations [Положение о съездах... 1904: 184; Справочная книга... 1916: 25-6]. Both regional representative corporations took an active part in a special meeting under the chairmanship of the Minister of Trade and Industry Dmitry A. Fiłosofow concerning the rights of workers (December 1906) [Государственный архив Ростовской..., 455, record 1, file 177: 93-106].

The principle of collectivity, as more effective and efficient, was used by industrialists not only in their region. Representatives were often delegated to conventions to another mining district. For example, a miner engineer Mikołaj F. von Ditmar was a representative of the South of Russia at the 5th Congress of Miners of the Kingdom of Poland (1899), he participat- 
ed in the activities of legal and statistical committees, as well as in "discussions on all questions that had at least the slightest interest for the southern mining industry" [Дитмар Н.Ф. 1900: 21]. The Congresses of the Miners of the South of Russia emphasized that "in the interests of the matter it would be very expedient for representatives of the Kingdom of Poland to be present at the Congresses of Miners of the South," and such representatives were to be given the right to vote [Труды XVIII съезда... 1894: LXXXII; Центральний державний.., 2161, record 1, file 235: 2]. This mutual exchange of delegates later became a constant phenomenon. Invited participants of the Congress of the South of Russia were Kazimierz I. Srokowski, Mieczysław L. Grabiński, Władysław L. Żukowski, Szczepan A. Jabloński, Józef E. Gieysztor and others. [Государственный архив Ростовской..., 455, record 1, file 219: thirty; Труды ХХІV съезда... 1900: IX; Отчет председателя ХХХІІІ съезда... 1909: 5].

Over time, a comprehensive and effective cooperation was established between the two Miners' Congresses: an agreement was reached on the systematization by the statistical office of the Southern Congresses of information on hard coal mining, smelting pig iron, prices for metallurgical goods of the Kingdom of Poland and on the creation of all-imperial statistics based on these data [Дитмар Н.Ф. 1900: 1].

Mining Congresses often synchronized their activities: they initiated fundamental petitions to the government, preparing materials on the same subject and publishing them in the press. Amo g others, in 1901 the 26th Kharkiv Congress dealt with the issue of heavy industry syndicates. The same idea was comprehensively discussed and supported by the 6th Congress of Miners of the Kingdom of Poland (1903) [Лурье Е. 1911: 9]. The cooperation between entrepreneurs undoubtedly enriched their experience, it allowed to use already proven organizational forms for implementation in their region. For example, the Second Congress of Miners of the Kingdom of Poland (1885) decided to equip the Mining School in Dąbrowa in an analogous way to the already existing Samuel S. Polakow Mining School at the Korsunska Mine in Donbas, [Труды II Съезда горнопромышленников Царства: Царства: VIII].

The logical result of the cooperation of representative organizations was the establishment of the All-Imperial Congress of Industry and Trade (1906, St. Petersburg). The leading regional conventions of entrepreneurs became the real participants of this "union of unions": the representative of the Congresses of the South of Russia was the miner engineer Vladimir I. Arandarenko; from the Congress of Miners of the Kingdom of 
Poland - businessman Władysław W. Żukowski [Деятельность Совета... 1908: 319].

During its entire existence, there were, in the South of Russia, 42 regular and 10 extraordinary Congresses of Mining Industrialists (1874-1919), and only 8 Congresses of Mining Industrialists of the Kingdom of Poland $(1883,1885,1893,1896,1899,1903,1910,1914)$ [Pietrzak-Pawłowska I. 1956: 344-5; Труды Первого... 1883; Труды ІІ Съезда... 1886; Труды ІІІ Съезда... 1893; Труды IV Съезда... 1897; Труды V-го Съезда...1900; Труды VI Съезда... 1903; Труды VII Съезда... 1910; Pustuła Z., Stanisław Skarbiński].

The events of the First World War interrupted the activity of the Congress of Mining Industrialists of the Kingdom of Poland, but did not stop it at all. After the declaration of independence of Poland, in 19181919, representation of the interests of entrepreneurs was continued by the Council of Congress in Warsaw [Frączak P., Towarzystwa...]. In 1920, all organizations of mining industrialists of Polish lands were united into the Association of Polish Mining and Metallurgical Engineers [Piłatowicz J. 2005: 242; Frączak P., Kazimierz Srokowski].

The work of the Congress of Mining Industrialists of the South of Russia was interrupted with the establishment of the Soviet power, intolerant to any manifestations of private initiative and market relations. The miners themselves were very critical of the «Soviet republic whose activities are a disgrace to culture and civilization and a threat to humanity» (according to the resolution of public organizations «Protest against Terror») [Центральний державний..., 2161, record 1, file 272: 38]. Attempts to restore the effective mechanisms of cooperation between the state and capital appeared in Ukraine only after the declaration of independence in 1991.

The structure and main directions of activities of the representative organizations of Mining Industrialists of the South of Russia and the Kingdom of Poland corresponded to the main changes of the post-reform era. The selected forms and methods of activity allowed to proudly present the views and interests of the economic elite of the society. The miners expressed satisfaction with their own achievements in the field of representation. Among others, a long-time chairman of the Council of Miners' Congresses of the South of Russia, Nikolai S. Awdakov, proudly noted in 1907 that "the history of mining in Russia for the third part of the century went hand in hand with the development of congresses, which, year after year, raise more and more important issues of economic life" [Экономическая история России... 2001: 90]. On the occasion of 
the 25th Jubilee of the Congress of Mining Industrialists of the South of Russia (1900), the newspaper "Новое время" wrote: "In the last quarter of a century, these congresses underwent a major metamorphosis: from the meeting of more or less modest, inconspicuous, shyly expressing opinions... The Congress of Miners of the South has become a large institution with hundreds of thousands... The development of the Miners' Congress as a social unit is no less impressive than the growth of the southern mining industry it represents" [Итоги горнопромышленного съезда 1900].

The congresses of mining industrialists played an important role in the development of industry in the Southern Economic Region and the Kingdom of Poland. On the forums of the «mining intelligentsia and mining wealthy aristocracy» [Письмо к редактору 1881], as their contemporaries called them, representatives of the business elite expressed all the current problems of industry, looked for a way to reconcile individual interests, formulated conclusions to government institutions, developed new industrial and financial projects, researched and used world and European experience.

\section{CONCLUSIONS}

The post-reform period in the Russian Empire is an era in which economic (practical) life developed faster than political (formal) life. The reality showed deep differences between the level of economic development and the importance of the economic elite in the socio-political life of the state. According to a modern proverb, "those were thinking, who were not producing." Representative mining organizations were an objective element of the capitalist transformation, when representatives of capital joined the process of making government decisions. The state did not have enough executive bodies to manage the development of the local economy, therefore social representative organizations were established to perform these functions.

Originally, all the regional industry representative organizations of the Empire were associated with a small number of industrialists, but by the beginning of the 20th century they gained considerable influence. In the press, representative organizations were often referred to as "bourgeois parliaments," and state measures of an economic nature, according to businessmen and officials, were introduced only after consultation with representative associations. 
The emergence of representative regional trade organizations in the political conditions of the Russian Empire in the second half of the nineteenth century was a unique phenomenon that testified to the depth and irreversibility of capitalist changes. The general economic growth achieved in the second half of the nineteenth and early twentieth centuries was the result of the effective organization of entrepreneurs and their ability to create mechanisms influencing the economic policy of the government.

\section{REFERENCES}

\section{Literature}

Дитмар Н.Ф. [Dytmar N.F.] (1900), V съезд горнопромышленников Царства Польского [5th Congress of Mining Industrialists of the Kingdom of Poland], Типография Зильберберг [Zilberberg Printing House], Харьков [Kharkov].

Добролюбов В.A. [Dobrolubow W.A.] (1888), О положении каменноугольной промышленности Донецкого бассейна и об отномении к ней ее руководителей и руководимых [On the condition of the coal industry of the Donetsk Basin and the attitude of its leaders and supervised]: в 2 ч. [in 2 parts], Тип. И. Н. Скороходова [I. N. Skorochodowa Publishing House], Санкт-Петербург [S.-Petersburg], Ч. 1. [Part 1].

Корнійчук Л.Я. [Kornijczuk L.J.] (1971), Суспільно-економічна думка на Україні в 70-х роках XIX cm. [Social and economic thought in Ukraine in the 1870s.], Видавництво Київського університету [Publishing House of the University of Kiev], Київ [Kiev].

Красильникова Т.К. [Krasilnikowa T.К. ] (2011), История корпоративного права России [History of Russian company law], Международный юридический институт [Institute of International Law], Москва [Moskow].

Крутіков В.В. [Krutikow W.W.] (1992), Буржуазія України та економічна політика цуаризму $b$ пореформений період [Ukrainian bourgeoisie and the economic policy of the tsarist regime in the post-reform period], Видавництво Дніпропетровського державного університету [Publishing House of Dnepropetrovsk] State University, Дніпропетровськ [Dnepropetrovsk].

Менделеев Д.И. [Mendelejew D.I.] (1960), Мировое значение каменного угля и Донецкого бассейна [Global importance of coal and the Donets Basin], [in:] Проблемы экономического развития России [Problems of economic development of Russia], Издательство социально-экономической литературы [Publishing House of Socio-economic literature], Москва [Moskow], 388-434.

Оржеховский И.В. [Orzechowski I.W.] (1974), Из истории внутренней политики самодержавия в 60-70-x годах XIX века [From the history of internal politics of autocracy in the 1860s and 1870s], Без издательства [Without publisher], Горький [Gorzki].

Piłatowicz J. (2005), Association movement of Polish engineers and technicians until 1939. Vol. II: Dictionary of Polish technical and scientific-technical associations until 1939. Supreme Technical Organization - Federation of Scientific and Technical Associations. FSNT NOT Chief Commission for Seniors and History of the Association Movement. Warsaw.

Туган-Барановский М. [Tugan-Baranowski M.] (1938), Русская фрабрика в прошлом и настоящем [Rosyjska fabryka dawniej i dziś], Соц.-экономическое издательство [Socio- 
есonomic Publishing House], Москва [Moskow], Т. 1: Историческое развитие русской фабрики в XIX веке [Volume 1. Historical development of the Russian factory in the 19th century].

Шандра I.O. [Szandra I.O.] (2011), 3'їзди гірничопромисловиів Півдня Росіӥ: створення та діяльність (1874-1918 pp.) [Congresses of Miners of the South of Russia: creation and activity], Видавництво Державного закладу «ЛНУ імені Тараса Шевченка» [Publishing House of State Institution „Lugansk” National University of Taras Shevchenko], Лyганськ [Lugansk].

Шандра I.O. [Szandra I.O.] (2016), Представницькі організації буржуазії украӥнських губерHiü (1861-1919 pp.) [Representative organizations of the bourgeoisie of the Ukrainian governorates (1861-1919)], Майдан [Publishing House Majdan], Харків [Kharkov].

Экономическая история России XIX - XX вb.: современный взгляд [Economic history of Russia in the nineteenth - twentieth centuries: contemporary look] (2001), РОССПЭН [Russian Political Encyclopedia - ROSSPEN], Москва [Moskow].

\section{Articles in journals}

Горнозаводское дело в минувшем году [Mining activities in the past year] (1875), Горный журнал [Mining Magazine], 1, 1-39.

Гушка А. О. [Guszka A. O.] (1912), Представительные организации торгово-промышиенного класса b России [Representative organizations of commercial and industrial class in Russia], Записки Императорского русского технического общества [Notes of the Imperial Russian Technical Society], 2, 41-61.

Kofman J. (1968), Warszawskie Towarzystwo Kopalń Wegla i Zakładów Hutniczych 1874-1918 : organizacja i ekomomika przedsiębiorstwa [Warsaw Society of Coal Mines and Metallurgical Works 1874-1918: organization and ecomics of the enterprise], Przegląd Historyczny, 59(1), 102-119.

Kowalczyk R.W. (2009), Wptyw rosyjskiej polityki protekcyjnej na sytuację gospodarcza Królestwa Polskiego w latach 1877-1914 [The influence of the Russian protection policy on the economic situation of the Kingdom of Poland in the years 1877-1914], Studia z Historii SpołecznoGospodarczej XIX i XX wieku, 6, 153-172.

Итоги горнопромышленного съезда [Results of the Mining Congress] (1900), Новое время [New Time], 8907 (12 дек.) [12 December], 5.

Лурье Е. [Łurije Е.] (1911), К характеристике предпинимательских организациии в России [On the characteristics of business organizations in Russia], Экономист России [Есоnimist of Russia], 16, 8-10.

Менделеев Д. И. [Mendelejew D. I.] (1888), Будущзая сила, покоящаяся на берегах Дониза [The future force that lies on the banks of the Donets], Северный вестник [Northern Bulletin], 12, 1-26.

Организация промышленников Царства Польского [Institution of Industrialists of the Kingdom of Poland] [подпись : М.Л.]. [Podpis: M.Ł.] (1911), Торгово-промышленный Юг [Commercial and industrial South], 1, 47-54.

Пажитнов К. [Pażytnow K.] (1907), Очерк развития буржуазии в Pоссии [An Outline of the development of the bourgeoisie in Russia]. Образование [Education], 2a, 1-23.

Pietrzak-Pawłowska I. (1956), Z dziejów monopolizacji górnictwa i hutnictwa w Królestwie Polskim (Zjazdy przemystowców górniczych w latach 1883-1914) [From the history of the monopolization of mining and metallurgy in the Kingdom of Poland (Meetings of mining industrialists in 1883-1914)], Kwartalnik Historyczny, 4/5(XLIII), 341-367.

Письмо к редактору [Letter to the editor] (1881), Южно-русский горный листок [South Russian mining leaflet], 6, 87. 
Съезд рыбо - и тюленепромыиленников [Congress of Fish and Seal Producers] (1908), Промышленность и торговля [Industry and Trade], 17, 265.

Третий съезд горнопромыиленников Царства Польского [Third Congress of Mining Industrialists of the Kingdom of Poland] (1893), Горный журнал [Mining Magazine], $1(3), 515-524$.

Шандра I. [Szandra I.] (2011), Класифікаиія підприемницьких союзіВ пореформеної доби [Classification of trade unions after the reform era], Волинські історичні записки [Volhynia historical notes] : Збірник наукових праць [Collection of scientific works], Вид-во ЖДУ ім. І. Франка [Publishing House of the State University of I. Franki in Zhytomyr], Житомир [Zhytomyr], 7, 43-48.

\section{Encyclopedias, dictionaries, lexicons}

Шандра И.А. [Szandra I.A.] (2014), Съезды горнопромыиленников Юга России [Congresses of Mining Industrialists of the South of Russia], [in:] Россия 6 Первой мировой Войне. 19141918 [Russia in the First World War]: энциклопедия [encyklopedia]: в 3 тт. / отв. редактор А.К. Сорокин [A.K. Sorokin (ed.)], Политическая энциклопедия [Political enсусlopedia], Москва [Moskow], Vol. 3: P-Я, 289-291.

Шандра И.А. [Szandra I.A.] (2016), Съезды горнопромышленников Юга России [Congresses of Mining Industrialists of the South of Russia], [in:] Большая российская энциклопедия [Great Russian Encyclopedia], Научн. изд-во «Большая российская энциклопедия» [Scientific Publishing House «Great Russian Encyclopedia»], Москва [Moskwa], 31: Социальное партнерство - Телевидение [[Social partnership - Television].

\section{Archives sources and records}

Государственный архив Ростовской области Российской Федераиии [State Archives of the Postorsky District of the Russian Federation], Юго-Восточное управление [SouthEastern Administration] (г. Новочеркасск) [m. Nowoczerkask], ф. 455, оп. 1, спр. 177 [455, record 1, file 177].

Государственный архив Ростовской области Российской Федерации [State Archives of the Postovsky District of the Russian Federation], Юго-Восточное управление [SouthEastern Administration] (г. Новочеркасск) [m. Nowoczerkask], ф. 455, оп. 1, спр. 219 [455, record 1, file 219].

Центральний державний історичний архіВ України В м. Києвi [Central State Historical Archives of Ukraine in Kiev], Совет Съездов горнопромышленников Юга России [Council of Mining Industrialists of the South of Russia] (г. Харьков) [Kharkov], ф. 2161, оп. 1, спр. 8 [2161, record 1 , file 8$]$.

Центральний державний історичний архіВ України В м. Києвi [Central State Historical Archives of Ukraine in Kiev], Совет Съездов горнопромышленников Юга России [Council of Mining Industrialists of the South of Russia] (г. Харьков) [Kharkov], ф. 2161, оп. 1, спр. 235 [2161, record 1, file 235].

Центральний державний історичнии архів України В м. Києвi [Central State Historical Archives of Ukraine in Kiev], Совет Съездов горнопромышленников Юга России [[Council of Mining Industrialists of the South of Russia] (г. Харьков) [Kharkov], ф. 2161, оп. 1, спр. 272 [2161, record 1, file 272].

\section{Sources published}

Ауэрбах А.А. [Auerbach А.А.] (1909), Воспоминания о начале развития каменноугольной промышленности В России [Meтmories about the beginnings of the coal industry in Russia], Русская старина [Russian antiquity], июнь [June], 451-472. 
Высочайше утвержденное положение Комитета Министров «Об учреждении горнопромышиенных съездов в Южнои России» [Highest approved decision of the Committee of the Ministers "About establishment of the Congresses of Miners in the South of Russia"] (1874), [in:] Собрание узаконений и распоряжений правительства, издаваемое при правительствующем Сенате [Collection of statutes and government orders issued by the ruling Senate], второе полугодие [second half-year], 60, 921.

Деятельность Совета наших Съездов [Activities of the Council of our Congresses] (1908), Промышленность и торговля [Industry and Trade], 5, 317-320.

Отчет председателя XXXIII съезда горнопромышленников Юга России В. А. Вагнера [Report of the chairman of the XXXIII Congress of Mining Industry of the South of Russia W.A. Wagner] (1909), Типография журнала «Мирный труд» [Printing house of the magazine „Peaceful work”], Харьков [Kharkov].

Положение о горнопромышленных съездах южной России [Decision concerning Congresses of Miners of the South of Russia] (1885), Южно-русский горный листок [South-Eastern mining leaflet], 119, 1547-1550.

Положение о горнопромышленных съездах южнои Poсcии [Decision concerning Congresses of Miners of the South of Russia] (1904), [in:] Девиер А.А. [Dewier A.A.], Бредов В.P. [Bredow W.R.], Свод постановлений о горнопромышиенности [Code of mining ordinances], Типография М.M. Стасюлевича [M.M. Stasiulewicz Printing House], СанктПетербург [S.-Petersburg], Vol. 1, 178-183.

Положение о съездах горнопромышиенников Царства Польского [Decision concerning Congresses of Miners of the Kingdom of Poland] (1904), [in:] Девиер А.А. [Dewier A.A.], Бредов B.P. [Bredow W.R.] Свод постановлений о горнопромышиенности [Code of mining ordinances]. Типография М.М. Стасюлевича [M.M. Stasiulewicz Printing House], Санкт-Петербург [S.-Petersburg], 1, 183-186.

Протоколы заседаний съезда углепромышиенников в Таганроге с 30-го сентября по 17-е октября 1877 года [Protocols of the meetings of the Congress of Mining Industiry in Taganrog from 30 September to 17 October 1977] (1877), Печатано в «Обл. В.Д.тип.» [Printed in the «Regional Printing House of Internal Affairs»], Новочеркасск [Nowoczerkask].

Свод законов Российской империи [Code of Laws of the Russian Empire] (1893), Издание кодификационного отдела при Государственном Совете [Publication of the Department of codification of the State Council], Санкт-Петербург [S.-Petrsburg], T. VII. Устав монетный и горный [Monetary and mining statete].

Свод законов Российской империи [Code of Laws of the Russian Empire] (no year). Издание неофициальное [Wydanie nieoficjalne]: в 5 кн. [in 5 volumes], Рус. книж. товарищество «Деятель» [Russian Book Association «Activist»], Санкт-Петербург [S.-Petersburg], Кн. 2 [vol. 2].

Справочная книга для горнопромышленников юга Pоссии [Information book for miners of the South of Russia]: в 2 ч. [in 2 parts] (1916), Тип. «Мирный труд» [Printing House «Peaceful Work»], Харьков [Kharkov], Ч. 1 [Part 1].

Труды Первого Съезда горнопромышленников Царства Польского, бывшего в городе Варшаве с 18-30 января по 26 января (7 фревраля) 1883 года [Works of the first Congress of Mining Industrialists of the Kingdom of Poland, in Warsaw from 18-30 January to 26 January (7 February) 1883.] (1883), Типография Эдуарда Гоппе [Edward Goppe Printing House], Санкт-Петербург [S.-Petersburg].

Труды II Съезда горнопромышленников Царства Польского, бывшего в городе Варшаве с 19 (31) октября по 26 октября (7 ноября) 1885 года [Works of the Second Congress of Mining Industrialists of the Kingdom of Poland, in Warsaw from 19 (31) October to 
26 October (7 November) 1885] (1886), Типография хромолитография А. Траншеля [A. Transzel's chromolithography printing house], Санкт-Петербург [S.-Petersburg]. Труды III Съезда горнопромышиенников Царства Польского, бывшего В гор. Варшаве c 27 фревраля (11 марта) nо 8 (20) марта 1893 года [Works of the Third Congress of Mining Industrialists of the Kingdom of Poland, in Warsaw from 27 February (11 March) do 8 (20) March 1893] (1893), Санкт-Петербург [S.-Petersburg].

Труды IV Съезда горнопромышиенников Царства Польского, бывшего в гор. Варшаве с 28 ноября (10 декабря) по 5 (17) декабря 1896 года (1897) [Works of the Fourth Congress of Mining Industrialists of the Kingdom of Poland, in Warsaw from 28 November (10 December) do 5 (17) December 1896] (1897), Домброва [Dąbrowa].

Труды V-го Съезда горнопромышленников Царства Польскаго, бывшаго в городе Варшаве с 25 ноября (7 декабря) по 5 (17) декабря 1899 г. [Works of the Fifth Congress of Mining Industrialists of the Kingdom of Poland, in Warsaw from 25 November (7 December) do 5 (17) Dec,ember 1899] (1900), Совет съезда горнопромышленников Царства Польского [Council of the Congress of Mining Industrialists of the Kingdom of Poland], Домброва [Dąbrowa], Ч. 2: Стенографические отчеты заседаний [Part 2: Verbatim record of meetings].

Труды VI Съезда горнопромышленников Царства Польского, бывшего в городе Варшаве с 14 (27) апреля по 21 апреля (4 мая) 1903 года [Works of the Sixth Congress of Mining Industrialists of the Kingdom of Poland, in Warsaw from 14 (27 April) do April (4 May) 1903] (1903), Совет съезда горнопромышленников Царства Польского [Council of the Congress of Mining Industrialists of the Kingdom of Poland], Домброва [Dąbrowa].

Труды VII Съезда горнопромышиенников Царства Польского, бывшего в городе Варшаве с 4 (17) мая по 9 (22) мая 1910 года [Works of the Seventh Congress of Mining Industrialists of the Kingdom of Poland, in Warsaw from 4 (17 May) do 9 (22 May) 1910] (1910), Тип. Ст. Свенского [St. Sweński's Printing House], Домброва [Dąbrowa], Ч. 1 : Отчеты, протоколы и доклады. [Part 1 : Reports, minutes; Ч. 2 : Стенографические отчеты заседаний [Part 2 : Verbatim records of meetings].

Труды XVIII съезда горнопромышиенников Юга Poсcuи [Works of the 18th Congress of Mining Industrialists of the South of Russia (1894), Типография Зильберберга [Zilberberg Printing House], Харьков [Kharkov], Ч. 1 [Part 1].

Труды XXIV съезда горнопромышленников Юга Poсcuи [Works of the 24th Congress of Mining Industrialists of the South of Russia (1900), Паровая типография и литография Зильберберг [Zilberberg steam printing and lithography], Харьков [Kharkov], Ч. 1 [Part 1].

\section{Online edition of journals}

Frączak P. Kazimierz Srokowski, http://asocjacje.org/w-poszukiwaniu-tradycji/kazimierzsrokowski/, accessed 20.08.2020.

Frączak P., Towarzystwa, stowarzyszenia, harcerze, http://dawnadabrowa.pl/etap2/catego ry/towarzystwa-stowarzyszenia-harcerze/page/6, accessed 20.08.2020.

Kazimierz Srokowski. http:/ / dawnadabrowa.pl/category/osoby/kazimierz-srokowski, accessed 20.08.2020.

Pustuła Z., Stanisław Skarbiński (1856-1925), Polish Online Biographical Dictionary. https:/ / www.ipsb.nina.gov.pl/a/biografia/stanislaw-skarbinski?print, accessed 20.08.2020.

Pustuła Z., Julian Teofil Strasburger (1847-1916), Polish Online Biographical Dictionary. https://www.ipsb.nina.gov.pl/a/biografia/julian-teofil-strasburger?print, accessed 20.08.2020. 
Iryna Shandra, Doctor of Historical Science, Professor of the Department of History, Museology and the Study of Historical Monuments, Kharkiv State Academy of Culture (Kharkiv, Ukraine). Scientific interests: social and economic history of Ukraine, history of entrepreneurship, trade relations and patronage.

Olena Kravchenko, Doctor of Historical Science, Associate Professor of the Department of History and Linguistics, Ukrainian State University of Railway Transport (Kharkiv, Ukraine). Scientific interests: social and economic history, history of charity, custody of children, history of Ukraine and Poland. 